\title{
Stroke due to calcific embolus following coronary angiography
}

\author{
P.N. Sylaja, MD; and Michael D. Hill, MD
}

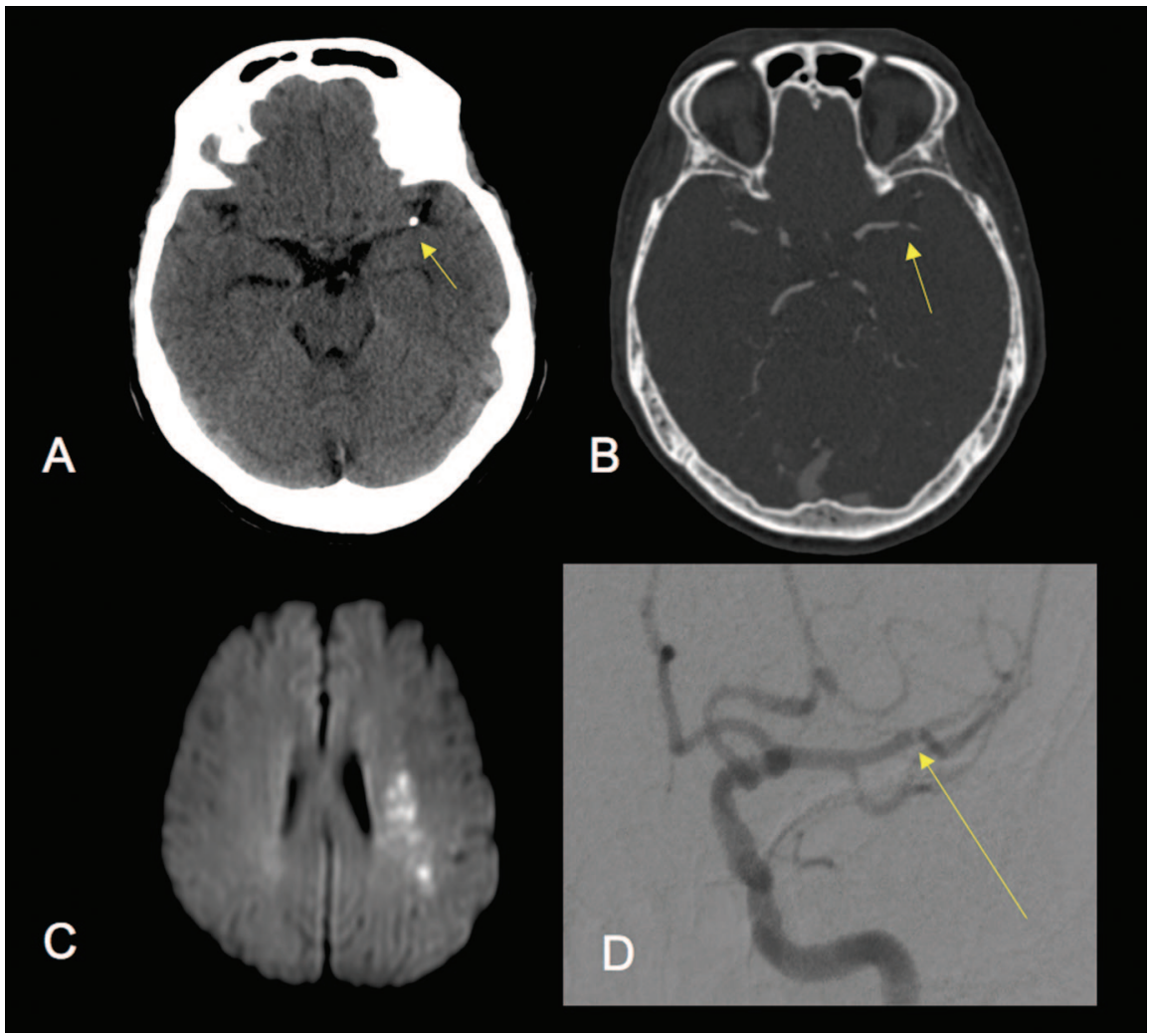

A 70-year-old right-handed, hypertensive woman underwent coronary angiography 5 days after a non-ST segment elevation myocardial infarction. Angiography showed a $90 \%$ narrowing of the left anterior descending artery. Toward the end of the procedure, she experienced fluctuating expressive dysphasia and mild right arm weakness. Head CT showed a calcific embolus in the left middle cerebral artery (figure, A, B). She stabilized with antiplatelet therapy and IV heparin but worsened the following day with global aphasia and right hemiplegia (figure, C). Surgical and endovascular embolectomy was considered (figure, D), but she developed anterior wall myocardial infarction with left ventricular failure and was treated conservatively. With normal cardiac valves on echocardiography, the calcific embolus probably originated from aortic plaque. Although the incidence of this complication is unknown,
Figure. (A) Noncontrast CT scan of the head showing a calcified embolus within the left middle cerebral artery (MCA). (B) CT angiography showing the calcified embolus with poor distal flow. (C) Diffusion-weighted MRI shows the acute ischemic lesion in the left MCA territory. (D) Digital substraction angiography showing the calcific embolus in the distal M1 with delayed filling in the superior division of MCA.

spontaneous embolization of calcific material commonly arises from calcific aortic or mitral valves. $^{1,2}$

\section{References}

1. Kirk GR, Johnson JK. Computed tomographic detection of a cerebral calcific embolus following coronary catheterization. J Neuroimaging 1994;4:241-242.

2. Halloran JI, Bekevac I. Unsuccessful tissue plasminogen activator treatment of acute stroke caused by a calcific embolus. J Neuroimaging 2004;14:385-387. 


\section{Neurology}

\section{Stroke due to calcific embolus following coronary angiography \\ P. N. Sylaja and Michael D. Hill \\ Neurology 2006;67;E16 \\ DOI 10.1212/01.wnl.0000242617.79359.d4}

\section{This information is current as of November 13, 2006}

\section{Updated Information \& Services}

References

Citations

Subspecialty Collections

Permissions \& Licensing

Reprints including high resolution figures, can be found at: http://n.neurology.org/content/67/9/E16.full

This article cites 2 articles, 0 of which you can access for free at: http://n.neurology.org/content/67/9/E16.full\#ref-list-1

This article has been cited by 1 HighWire-hosted articles: http://n.neurology.org/content/67/9/E16.full\#\#otherarticles

This article, along with others on similar topics, appears in the following collection(s):

All Cerebrovascular disease/Stroke

http://n.neurology.org/cgi/collection/all_cerebrovascular_disease_strok e

Cardiac

http://n.neurology.org/cgi/collection/cardiac

Infarction

http://n.neurology.org/cgi/collection/infarction

Information about reproducing this article in parts (figures,tables) or in its entirety can be found online at:

http://www.neurology.org/about/about_the_journal\#permissions

Information about ordering reprints can be found online:

http://n.neurology.org/subscribers/advertise

Neurology ${ }^{\circledR}$ is the official journal of the American Academy of Neurology. Published continuously since 1951, it is now a weekly with 48 issues per year. Copyright . All rights reserved. Print ISSN: 0028-3878. Online ISSN: 1526-632X.

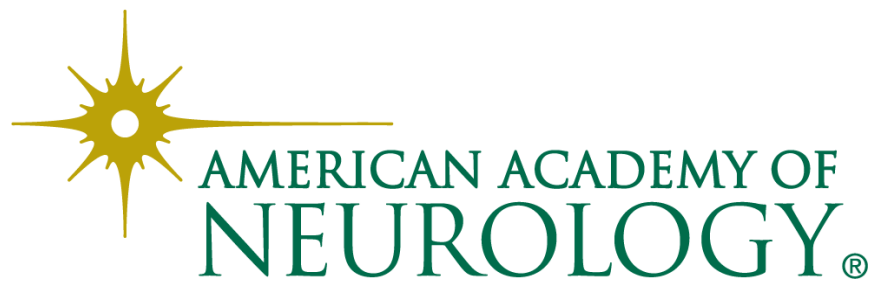

